\title{
Ectomycorrhizal fungi associated with two species of Kobresia in an alpine meadow in the eastern Himalaya
}

\author{
Qian Gao · Zhu L. Yang
}

Received: 30 June 2009 / Accepted: 12 November 2009/Published online: 12 December 2009

(C) The Author(s) 2009. This article is published with open access at Springerlink.com

\begin{abstract}
The diversity of ectomycorrhizal fungi (EMF) on Kobresia filicina and Kobresia capillifolia in an alpine meadow in China's southwestern mountains, one of the word's hotspots of biodiversity, was estimated based on internal transcribed spacer rDNA sequence analysis of root tips. Seventy EMF operational taxonomical units (OTUs) were found in the two plant species. Dauciform roots with EMF were detected in species of Kobresia for the first time. OTU richness of EMF was high in Tomentella/Thelophora and Inocybe, followed by Cortinarius, Sebacina, the Cenococcum geophilum complex, and Russula. Tomentella/Thelophora and Inocybe were general and dominant mycobiont genera of the two sedges. Besides the $C$. geophilum complex, the ascomycete components Hymenoscyphus and Lachnum were also detected on the two plants. Alpine plants in different geographical regions share similar main genera and/or families of EMF while harboring predominantly different mycobiont species; most of the members detected by us have not been found elsewhere. Significant differences in the profile of EMF occurrences were not found between the two plant species and among the three sampling seasons in our sample size.
\end{abstract}

Electronic supplementary material The online version of this article (doi:10.1007/s00572-009-0287-5) contains supplementary material, which is available to authorized users.

Q. Gao $\cdot$ Z. L. Yang $(\bowtie)$

Key Laboratory of Biodiversity and Biogeography, Kunming Institute of Botany, Chinese Academy of Sciences, Kunming 650204, People's Republic of China e-mail: fungi@mail.kib.ac.cn

Q. Gao

Graduate University of Chinese Academy of Sciences, Beijing 100049, People's Republic of China
Keywords Mycobiont Kobresia Alpine meadow . Dauciform root $\cdot$ ITS rDNA

\section{Introduction}

Mycorrhizae are likely to be of importance in nutrientstressed or infertile environments, such as alpine areas. Forming ectomycorrhizal (EM) associations is one of the most ecologically important symbiotic associations in terrestrial ecosystems (Smith and Read 1997; Cairney and Chambers 1999; Rinaldi et al. 2008) and is believed to be a crucial and effective way of alleviating nutritional stress for both plants and fungi in alpine areas. EM are common on alpine woody plants (Wang and Qiu 2006) and have also been detected on several alpine/arctic grasses (Wang and Qiu 2006; Moreau et al. 2006; Li and Guan 2007).

Grasses in the Cyperaceae (the sedge family) are common in stressed habitats like alpine/arctic areas. Recent studies have revealed that many species in the Cyperaceae are mycorrhizal (Muthukumar et al. 2004). Ectomycorrhizal (EM) and/or ectomycorrhizal fungi (EMF) communities on Kobresia myosuroides (Villars) Foiri $[=K$. bellardii (All.) Degel] were reported or characterized in many works (Fontana 1963; Haselwandter and Read 1980; Read and Haselwandter 1981; Kohn and Stasovski 1990; Gardes and Dahlberg 1996; Massicotte et al. 1998; Lipson et al. 1999; Schadt and Schmidt 2001; Ali and Hossein 2008; Mühlmann and Peintner 2008b). In addition, many more common sedge species in nutrient-poor environments have been found to form "dauciform roots," which are specialized structures produced as morphological and physiological adaptations of plants to nutrient adversities and may have a similar function in mycorrhizae in nutrient acquisition (Shane et al. 2006). 
Kobresia filicina (C. B. Clarke) C. B. Clarke and Kobresia capillifolia (Decne.) C. B. Clarke, together with other grasses of Potentilla and Polygonum, are dominant plant species in the easternmost Himalaya and in the mountains of southwest China (Wu and Zhu 1987; Zhou 2001), one of the world's hotspots of biodiversity. Forming mycorrhizal associations may be one of their important means for alleviating nutritional stress in alpine environments. Nothing, however, is known about the EMF status of plants in the region. In addition, it is intriguing to determine whether dauciform roots occur on species of Kobresia that grow there and whether they form EM. The objectives of this work were (1) to identify diversity of EMF on the two species of Kobresia in an alpine meadow in the region and (2) to determine whether dauciform roots occur on species of Kobresia and whether they form EM to survive the alpine stress.

\section{Materials and methods}

\section{Sampling and sample processing}

The sampling site was an alpine meadow (altitude, $4,300 \mathrm{~m})$ on Hong Shan $\left(27^{\circ} 50^{\prime} \mathrm{N}, 9^{\circ} 24^{\prime} \mathrm{E}\right)$, Shangri-La County (Zhongdian) in Yunnan Province, southwest China. Sampling of K. filicina and K. capillifolia was performed in mid-May (spring), late July (summer), and early September (autumn) 2007. Samples were randomly collected within a $50 \times 50-\mathrm{m}^{2}$ square 5-6 $\mathrm{m}$ away from each other. Plants (including their roots and aboveground parts) and surrounding soil were excavated, resulting in plots measuring about $30 \times 20 \times 20$ (length, width, and depth) $\mathrm{cm}$ each. Ten samples were made for each plant species on each sampling date, resulting in 60 samples in total. The occasionally occurring sporocarps around or near the sampling plots were collected to obtain reference sequences for identification of the EMF.

Ectomycorrhizal root tips were examined at $\times 3$ magnification under a dissecting microscope and macroscopically sorted into morphotypes based on color, mantle surface, ramification pattern, and occurrence of emanating hyphae (Agerer 2006). Dauciform roots were examined and sorted by color. At least $10-20$ root tips of an individual morphotype were stored in saturated $\mathrm{NaCl} / \mathrm{CTAB}$ solution at $-20^{\circ} \mathrm{C}$ until used in molecular investigations.

PCR and sequence analyses of the ITS rDNA region

DNA was extracted from root tips following the procedures of Hibbett and Vilgalys (1993) with several modifications. Primer combinations of ITS1F $\times$ ITS4 (Gardes and Bruns 1993), ITS5 $\times$ ITS4, and ITS1F $\times$ LR1 were used to amplify the rDNA internal transcribed spacer (ITS) region. PCR products were sequenced after cloning.

After blast searching against GenBank and UNITE databases, sequences were sorted into operational taxonomical units (OTUs), which were defined as sequences with at least $97 \%$ similarity and regarded as belonging to one species (Mühlmann et al. 2008; Mühlmann and Peintner 2008a, b). Our ITS rDNA sequences are deposited in GenBank as accession numbers FJ581421, FJ581422, and FJ378717-FJ378866.

\section{Statistical analyses}

Frequency of an EMF OTU was defined as the number of samples from which the OTU was detected. Chi-square test was performed with SAS software (The SAS system for Windows 9.0), with frequency of OTUs used as the dependent variable, "plant species" and "season" as independent variables, respectively. The significance level was set as 0.05 . Diversity measures per sample included diversity index $(H)$ of Shannon and Wiener (1949), species richness index $(R)$ of Margalef (1958), and evenness index (E) of Pielou (1969). Kruskal-Wallis test was performed, with average Shannon and Wiener's diversity index per sample used as the dependent variable, "plant species" and "season" as independent variables, respectively, and the significance level was set as 0.05 .

\section{Results}

EMF diversity of the two plants

Eight ectomycorrhizal morphotypes were found on the two species of Kobresia. Sixty seven EMF OTUs were obtained from their ectomycorrhizal root tips and 11 from the dauciform roots (eight of them were also found on ectomycorrhizal root tips; Table 1). Total OTU richness of EMF (including both plant species and three seasons) was 70. Most (59) were basidiomycetes, and 11 were ascomycetes. OTU richness was high in Tomentella/Thelophora (16) and Inocybe (15), followed by Cortinarius (seven), Sebacina (seven), the Cenococcum geophilum complex (seven), and Russula (five) (Supplementary Figs. 1-4) while low in Lachnum (two), Hymenoscyphus (two), Amanita (two), Laccaria (two), Lactarius (two), Hebeloma (one), and Boletus (one). Seventy percent of the total OTUs (49 OTUs) were detected only once, and several OTUs closely matched EMF in Europe (Table 1). It should be noted that the EMF of Boletus reticuloceps and Lactarius 01 was identified based on its high similarity to the sporocarps of B. reticuloceps (FJ548566) and Lactarius subsphagneti (FJ378814), respectively (Table 1). 
Table 1 Mycobionts on K. filicina and K. capillifolia

\begin{tabular}{|c|c|c|c|c|}
\hline \multirow[t]{2}{*}{ EMF OTUs } & \multicolumn{2}{|c|}{ Frequency } & \multicolumn{2}{|c|}{ Closest match and accession number } \\
\hline & $\begin{array}{l}\text { By } \\
\text { plant }\end{array}$ & By season & In GenBank & In UNITE database \\
\hline
\end{tabular}

\begin{tabular}{|c|c|c|c|c|c|c|c|}
\hline Amanita 01 & 1 & 0 & 0 & 1 & 0 & A. velosa (92\%) DQ974692 & Amanita sp. (1,061 bits) UDB000929 \\
\hline Amanita 02 & 0 & 1 & 0 & 1 & 0 & A. vaginata (91\%) AJ889925 & A. mortenii (757 bits) UDB002235 \\
\hline Boletus reticuloceps & 0 & 2 & 0 & 2 & 0 & B. reticuloceps (100\%) FJ548566 & \\
\hline Sebacina 01 & 1 & 0 & 0 & 1 & 0 & & Sebacina sp. (416 bits) UDB000774 \\
\hline Sebacina 02 & 1 & 0 & 1 & 0 & 0 & Sebacina EM (83\%) AB218165 & \\
\hline Sebacina 03 & 3 & 1 & 3 & 0 & 1 & Sebacina EM (97\%) AF440652 & Sebacina sp. (660 bits) UDB000774 \\
\hline Sebacina 04 & 0 & 1 & 1 & 0 & 0 & Sebacina EM (98\%) AF440648 & Sebacina sp. (789 bits) UDB000773 \\
\hline Sebacina 05 & 1 & 1 & 0 & 0 & 2 & Sebacina EM (97\%) AF440648 & Sebacina sp. (765 bits) UDB000773 \\
\hline Sebacina 06 & 0 & 1 & 0 & 0 & 1 & Sebacina sp. (95\%) EF433975 & \\
\hline Sebacina 07 & 1 & 0 & 0 & 1 & 0 & Sebacina EM (96\%) AY940653 & \\
\hline Cortinarius 01 & 1 & 0 & 0 & 0 & 1 & $\begin{array}{l}\text { C. psammocephalus }(95 \%) \\
\text { AY669672 }\end{array}$ & \\
\hline Cortinarius 02 & 0 & 1 & 0 & 1 & 0 & $\begin{array}{l}\text { Cortinarius EM (98\%) } \\
\text { AY641471 }\end{array}$ & $\begin{array}{l}\text { C. psammocephalus ( } 1,118 \text { bits }) \\
\text { UDB002161; } C \text {. diasemospermus } \\
\text { (1,172 bits) UDB001230 }\end{array}$ \\
\hline Cortinarius 03 & 1 & 1 & 0 & 0 & 2 & $\begin{array}{l}\text { C. umbrinolens }(95 \%) \text { AY } 669658 ; \\
\text { Cortinarius EM (99\%) AY748857 }\end{array}$ & \\
\hline Cortinarius 04 & 0 & 1 & 1 & 0 & 0 & C. flexipes (96\%) AJ889971 & C. flexipes (1,029 bits) UDB000063 \\
\hline Cortinarius $\mathbf{0 5}$ & 1 & 0 & 0 & 0 & 1 & C. cf. saniosus (98\%) DQ102683 & $\begin{array}{l}\text { C. rubrovioleipes (1,074 bits) } \\
\text { UDB001453 }\end{array}$ \\
\hline Cortinarius 06 & 1 & 0 & 0 & 0 & 1 & C. cf. saniosus (98\%) DQ102683 & $\begin{array}{l}\text { C. diasemospermus (1,150 bits) } \\
\text { UDB001230 }\end{array}$ \\
\hline Cortinarius 07 & 0 & 1 & 0 & 0 & 1 & C. parvannulatus (89\%) AY669664 & $\begin{array}{l}\text { C. diasemospermus (731 bits) } \\
\text { UDB001230 }\end{array}$ \\
\hline Inocybe 01 & 1 & 0 & 0 & 0 & 1 & I. pudica (89\%) AY228341 & \\
\hline Inocybe 02 & 0 & 2 & 0 & 2 & 0 & Inocybe EM (88\%) EF218781 & \\
\hline Inocybe 03 & 2 & 1 & 1 & 2 & 0 & Inocybe EM (94\%) EF641838 & I. rimosa (1,017 bits) UDB000103 \\
\hline Inocybe 04 & 1 & 0 & 1 & 0 & 0 & Inocybe EM (94\%) EF641838 & I. rimosa (987bits) UDB000103 \\
\hline Inocybe 05 & 1 & 1 & 1 & 0 & 1 & $\begin{array}{c}\text { Inocybe EM (93\%) AY940653; } \\
\text { I. egenula }(95 \%) \text { AM } 882714\end{array}$ & \\
\hline Inocybe 06 & 2 & 2 & 3 & 0 & 1 & Inocybe EM (91\%) EF218773 & I. aurea (521 bits) UDB000612 \\
\hline Inocybe 07 (I. umbrina) & 0 & 1 & 1 & 0 & 0 & EM (89\%) AB218065 & I. umbrina (545 bits) UDB000608 \\
\hline Inocybe 08 (I. acutella) & 1 & 0 & 0 & 0 & 1 & I. acutella (96\%) AM882923 & I. acutella (910 bits) UDB000609 \\
\hline Inocybe 09 & 1 & 1 & 1 & 1 & 0 & I. cf.lanuginosa (92\%) EU525979 & \\
\hline Inocybe 10 & 0 & 1 & 0 & 0 & 1 & I. cf. hirculus (92\%) AM882986 & \\
\hline Inocybe 11 & 1 & 0 & 1 & 0 & 0 & I. egenula $(96 \%)$ AM882714 & \\
\hline Inocybe 12 & 1 & 2 & 2 & 1 & 0 & $\begin{array}{l}\text { I. egenula }(95 \%) \text { AM882714; Inocybe } \\
\text { EM (95\%) AY940653 }\end{array}$ & \\
\hline Inocybe 13 & 1 & 0 & 1 & 0 & 0 & I. egenula $(95 \%)$ AM 882714 & \\
\hline Inocybe 14 & 0 & 2 & 1 & 0 & 1 & $\begin{array}{l}\text { I. pudica }(89 \%) \text { AY228341; EM(93\%) } \\
\text { AY940653 }\end{array}$ & \\
\hline Inocybe 15 & 0 & 1 & 0 & 1 & 0 & I. aff.lanuginosa (93\%) EU486457 & I. calamistrata (777 bits) UDB001195 \\
\hline Hebeloma 01 & 1 & 2 & 0 & 0 & 3 & $\begin{array}{l}\text { H. mesophaeum }(97 \%) \text { AB } 211272 ; \\
\text { H. albocolossum }(99 \%) \text { AY } 308583\end{array}$ & H. velutipes (918 bits) UDB002445 \\
\hline Laccaria 01 & 1 & 0 & 0 & 1 & 0 & L. bicolor (98\%) DQ097876 & L. amethystine (1,394 bits) UDB000006 \\
\hline Laccaria 02 & 1 & 0 & 0 & 0 & 1 & EM (94\%) AB218097 & L. laccata (1,255 bits) UDB000106 \\
\hline Tomentella 01 & 1 & 0 & 0 & 0 & 1 & Tomentella EM (95\%) EF218826 & T. bryophila (955 bits) UDB000035 \\
\hline Tomentella 02 & 1 & 0 & 0 & 1 & 0 & Tomentella EM (93\%) EF218826 & Tomentella sp. (904 bits) UDB001658 \\
\hline Tomentella 03 & 2 & 1 & 3 & 0 & 0 & T. ramosissima (95\%) U83480 & T. lapida (1,088 bits) UDB001657 \\
\hline Tomentella 04 & 1 & 0 & 1 & 0 & 0 & T. ramosissima (93\%) U83480 & T. lapida (920 bits) UDB001657 \\
\hline Tomentella 05 & 1 & 0 & 0 & 1 & 0 & Thelephoraceae EM (93\%) AY825525 & T. caryophyllea (886 bits) UDB000119 \\
\hline Tomentella 06 & 0 & 1 & 1 & 0 & 0 & Thelephora EM (96\%) EF655695 & T. caryophyllea (932 bits) UDB000119 \\
\hline Tomentella 07 & 1 & 0 & 1 & 0 & 0 & Thelephoraceae EM (92\%) EF825525 & T. penicillata ( 1,080 bits) UDB000775 \\
\hline
\end{tabular}


Table 1 (continued)

\begin{tabular}{|c|c|c|c|c|c|c|c|}
\hline \multirow[t]{3}{*}{ EMF OTUs } & \multicolumn{5}{|c|}{ Frequency } & \multicolumn{2}{|l|}{ Closest match and accession number } \\
\hline & \multicolumn{2}{|c|}{$\begin{array}{l}\text { By } \\
\text { plant }\end{array}$} & \multicolumn{3}{|c|}{ By season } & \multirow[t]{2}{*}{ In GenBank } & \multirow[t]{2}{*}{ In UNITE database } \\
\hline & $\mathrm{Kc}$ & $\mathrm{Kf}$ & May & July & September & & \\
\hline Tomentella 08 & 1 & 0 & 0 & 1 & 0 & T. caryophyllea (94\%) AJ889980 & $\begin{array}{l}\text { T. caryophyllea (1,049 bits) } \\
\text { UDB000119 }\end{array}$ \\
\hline Tomentella 09 & 2 & 1 & 1 & 1 & 1 & Tomentella EM (96\%) EF218831 & T. bryophila (831 bits) UDB000035 \\
\hline Tomentella 10 & 3 & 0 & 0 & 0 & 3 & Thelephoraceae EM (97\%) EF077519 & T. stuposa (1,065 bits) UDB000248 \\
\hline Tomentella 11 & 1 & 0 & 0 & 0 & 1 & Tomentella EM (100\%) EF218830 & T. badia (914 bits) UDB001656 \\
\hline Tomentella 12 & 1 & 0 & 1 & 0 & 0 & Tomentella EM (100\%) EF218830 & $\begin{array}{l}\text { T. atramentaria (1,088 bits) } \\
\text { UDB000235 }\end{array}$ \\
\hline $\begin{array}{l}\text { Tomentella } 13 \\
\text { (T. atramentaria) }\end{array}$ & 1 & 0 & 1 & 0 & 0 & Tomentella EM (98\%) AY748876 & $\begin{array}{l}\text { T. atramentaria (1,013 bits) } \\
\text { UDB000955 }\end{array}$ \\
\hline Tomentella 14 (T. badia) & 0 & 1 & 1 & 0 & 0 & Tomentella EM (100\%) EF218830 & T. badia (1,037 bits) UDB001656 \\
\hline Thelephoraceae 01 & 1 & 0 & 1 & 0 & 0 & Tomentella EM (100\%) EF218830 & T. badia (599 bits) UDB000961 \\
\hline Thelephoraceae 02 & 0 & 1 & 0 & 1 & 0 & Tomentella EM (86\%) EU326163 & \\
\hline Russula 01 & 1 & 1 & 1 & 1 & 0 & R..cuprea (97\%) AY061667 & R. cuprea (1,170 bits) UDB002457 \\
\hline Russula 02 & 0 & 1 & 1 & 0 & 0 & & R. sanguinea (965 bits) UDB001634 \\
\hline Russula 03 & 5 & 2 & 1 & 0 & 6 & Russulaceae sp. (97\%) DQ061886 & R. chloroides (1,207 bits) UDB002496 \\
\hline Russula 04 & 2 & 0 & 0 & 0 & 2 & Russula EM (97\%) EF218798 & R. chloroides (1,164 bits) UDB002496 \\
\hline Russula 05 (R. pallescens) & 1 & 0 & 1 & 0 & 0 & R. pallescens (96\%) DQ421987 & R. pallescens ( 1,047 bits) UDB002461 \\
\hline $\begin{array}{l}\text { Lactarius } 01 \\
\quad \text { (L.subsphagneti) }\end{array}$ & 1 & 3 & 0 & 3 & 1 & L. subsphagneti (99\%) FJ378814 & L. aurantiacus (1,411 bits) UDB000887 \\
\hline $\begin{array}{l}\text { Lactarius } 02 \\
\quad \text { (L. spinosulus) }\end{array}$ & 0 & 1 & 0 & 0 & 1 & L. spinosulus (97\%) AY606955 & L. spinosulus (1,366 bits) UDB000373 \\
\hline Russulaceae 01 & 1 & 0 & 0 & 0 & 1 & L. spinosulus (96\%) AY606955 & L. spinosulus (807 bits) UDB000373 \\
\hline Hymenoscyphus 01 & 0 & 1 & 0 & 0 & 1 & Ascomycete EM (98\%) AJ534703 & H. ericae ( 886 bits) UDB 000515 \\
\hline Hymenoscyphus 02 & 1 & 2 & 1 & 1 & 1 & & H. ericae (694 bits) UDB000509 \\
\hline Lachnum 01 & 2 & 1 & 3 & 0 & 0 & & $\begin{array}{l}\text { L. brevipilosum (1,011 bits) } \\
\text { UDB003074 }\end{array}$ \\
\hline Lachnum 02 & 1 & 1 & 0 & 0 & 2 & & $\begin{array}{l}\text { L. brevipilosum (1,041 bits) } \\
\text { UDB003074 }\end{array}$ \\
\hline C. geophilum 01 & 1 & 0 & 0 & 1 & 0 & C. geophilum (92\%) AY394919 & C. geophilum (654 bits) UDB002301 \\
\hline Hymenogastraceae $01^{\mathrm{a}}$ & 1 & 3 & 2 & 0 & 2 & $\begin{array}{l}\text { Hymenogaster rubyensis }(91 \%) \\
\text { AY } 945303\end{array}$ & \\
\hline Helotiales $01^{\mathrm{a}}$ & 0 & 2 & 1 & 0 & 1 & Helotiales sp. (97\%) EF093147 & \\
\hline Helotiales $02^{\mathrm{a}}$ & 0 & 1 & 1 & 0 & 0 & Helotiales EM (99\%) EU326174 & \\
\hline Helotiales $03^{\mathrm{a}}$ & 0 & 1 & 1 & 0 & 0 & Helotiales sp. (97\%) EF093147 & \\
\hline Acephala sp. ${ }^{\mathrm{a}}$ & 0 & 1 & 0 & 0 & 1 & Acephala sp.(98\%) EU434831 & $\begin{array}{l}\text { Hysteronae viascirpina (904 bits) } \\
\text { UDB003025 }\end{array}$ \\
\hline Phialocephala sp. ${ }^{\mathrm{a}}$ & 0 & 1 & 1 & 0 & 0 & P. sphaeroides (90\%) EU434851 & \\
\hline Leptodontidium sp. ${ }^{\mathrm{a}}$ & 0 & 1 & 0 & 0 & 1 & L. orchidicola (98\%) EU436691 & \\
\hline Pleiochaeta sp. $^{\mathrm{a}}$ & 1 & 0 & 0 & 0 & 1 & P. ghindensis (97\%) EU167561 & \\
\hline Cistella sp. $^{\mathrm{a}}$ & 0 & 1 & 0 & 0 & 1 & & C. fugiens (654 bits) UDB003082 \\
\hline Naeviopsis sp. ${ }^{\mathrm{a}}$ & 2 & 5 & 3 & 1 & 3 & Helotiales sp. (98\%) EF093150 & N. arctica (900 bits) UDB003042 \\
\hline Microglossum sp. ${ }^{\text {a }}$ & 2 & 0 & 1 & 0 & 1 & M. viride (99\%) AY144534 & $\begin{array}{l}\text { Psilocistella alchemillae (559 bits) } \\
\text { UDB003089 }\end{array}$ \\
\hline Hyalacrotes sp. ${ }^{\mathrm{a}}$ & 1 & 0 & 0 & 0 & 1 & & H. hamulata (892 bits) UDB003006 \\
\hline Pseudeurotium sp. ${ }^{\text {a }}$ & 0 & 1 & 0 & 0 & 1 & Pseudeurotium backeri (99\%) DQ068995 & \\
\hline
\end{tabular}

Identification, frequency of OTUs, best blast matches in GenBank, and/or UNITE with identity (percent or bits number) and accession number are shown. Frequency by plant species included samples from all three seasons; frequency by season included samples of both plant species. OTUs in bold include individuals isolated from dauciform roots. May, July, and September are the sampling dates

Kf, K. filicina; Kc, K. capillifolia

${ }^{a}$ Probably plant endophytes 
Table 2 Average EMF diversity measures per sample on K. filicina and K. capillifolia

\begin{tabular}{|c|c|c|c|c|c|c|c|c|}
\hline \multirow[t]{3}{*}{ Index } & \multicolumn{2}{|c|}{ Samples/species } & \multicolumn{6}{|c|}{ Samples/season/species } \\
\hline & \multirow[t]{2}{*}{$\mathrm{Kf}$} & \multirow[t]{2}{*}{$\mathrm{Kc}$} & \multicolumn{3}{|l|}{$\mathrm{Kf}$} & \multicolumn{3}{|l|}{$\mathrm{Kc}$} \\
\hline & & & May & July & Sept. & May & July & Sept. \\
\hline Richness & 1.253 & 1.288 & 1.363 & 1.165 & 1.204 & 1.252 & 1.430 & 1.252 \\
\hline Diversity & 0.667 & 0.672 & 0.679 & 0.659 & 0.663 & 0.668 & 0.686 & 0.667 \\
\hline Evenness & 0.964 & 0.968 & 0.980 & 0.950 & 0.955 & 0.964 & 1 & 0.964 \\
\hline
\end{tabular}

Diversity measures including species richness index, diversity index and evenness index are presented for samples of each plant species, and for samples of each season for each plant species separately

Kf, K. filicina; Kc, K. capillifolia

Thirty-nine EMF OTUs assigned to 12 genera were found on K. filicina and 54 of 12 genera were found on $K$. capillifolia. OTU richness was high in Inocybe (ten) for $K$. filicina and high in Tomentella/Thelophora (13) and Inocybe (12) for $K$. capillifolia. Twenty OTUs occurred on both plant species; richness was high in Inocybe (six).

For K. filicina, 16 OTUs assigned to seven genera were detected from samples collected in May, 12 of nine genera from July, and 15 of nine genera from September. OTU richness was high in Inocybe (five) and Tomentellal Thelophora (three) for May, high in Inocybe (three) for July, and high in Inocybe (four) for September. Four OTUs were present during more than one season.

For $K$. capillifolia, 24 OTUs assigned to seven genera were detected from samples of May, 13 of seven genera from July, and 23 of ten genera from September. OTU richness was high in Tomentella/Thelophora (seven) and Inocybe (six) for May, high in Inocybe (four) and Tomentella/Thelophora (three) for July, and high in Cortinarius (four), Inocybe (three), and Tomentella/Thelophora (four) for September. Six OTUs were present during more than one season.

According to the chi-square test, there were no statistically significant differences of EMF occurrence between the two plant species ( $p=0.4211$ for samples collected in all seasons; $p=0.8079$ for samples in May, $p=0.7064$ for July, and $p=0.2799$ for September) and among the three sampling seasons ( $p=0.7640$ for K. filicina, $p=0.2856$ for K. capillifolia). According to the Kruskal-Wallis test, there were no statistically significant differences of average Shannon and Wiener's diversity indices per sample between the two plant species ( $p=0.6106$ for samples of all seasons; $p=0.3042$ for samples in May, $p=0.0555$ for July, and $p=0.6862$ for September) and among seasons ( $p=$ 0.2902 for K. filicina and $p=0.2676$ for $K$. capillifolia). Average diversity measures per sample by plant species and by season are shown in Table 2 .

\section{Dauciform roots with EMF}

Dauciform roots were detected in 19 samples $(31.7 \%$ of the total samples) of the two species of Kobresia. They were carrot-shaped lateral roots generally connected to the parent roots by a peduncle and white, pale yellow, orange, or beige (Fig. 1a). Some of the dauciform roots extending directly from the parent roots without a peduncle were white or occasionally beige. They were initially smooth but turned brush-like due to long, dense root hairs when mature (Fig. 1b). Typical ectomycorrhizal characters, i.e., mantle and Hartig's net, were not detected on them, but fungal hyphae were observed on their surface (Fig. 1c). Eleven EMF OTUs were obtained from them, including members
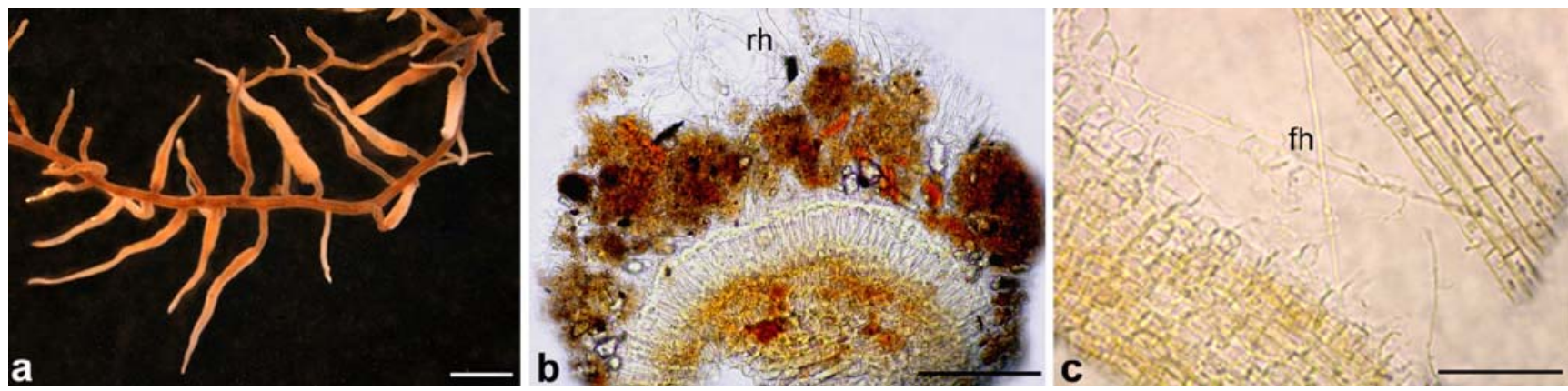

Fig. 1 Dauciform roots of $K$. filicina with EMF. a Macromorphology of dauciform roots. b Transverse section of a dauciform root ( $r h$ root hairs). c Vertical section of a dauciform root ( $f$ f fungal hyphae). Scale bar is $1 \mathrm{~mm}$ for $\mathbf{a}, 250 \mu \mathrm{m}$ for $\mathbf{b}$, and $500 \mu \mathrm{m}$ for $\mathbf{c}$ 
in Russula, Lactarius, Tomentella/Thelophora, Cortinarius, Sebacina, Hymenoscyphus, and Lachnum. OTU richness was high in Russulaceae (four).

\section{Discussion}

Mycobiont diversity of alpine plants

Based on former studies of alpine areas in Europe and North America (Gardes and Dahlberg 1996; Schadt and Schmidt 2001; Mühlmann et al. 2008; Mühlmann and Peintner 2008a, b), Inocybe, Cortinarius, Tomentella/ Thelophora, Russula, and Lactarius are the main arcticalpine ectomycorrhizal genera. Our study in an alpine meadow of southwest China found a similar assemblage. It is evident that alpine plants in different geographical regions share similar main mycobiont genera and/or families. There were regional differences at the species level, however, since most of the EMF OTUs detected have not been found elsewhere.

In our study, the ascomycete mycobionts Hymenoscyphus and Lachnum were detected on the two species of Kobresia, suggesting that further attention to ascomycete mycobionts in addition to the C. geophilum complex is needed in future studies. Other ascomycetes, including species of Helotiales (besides Hymenoscyphus spp. and Lachnum spp.), were detected on ectomycorrhizal root tips and the dauciform roots of the two species of Kobresia, and ascomycete mycobionts of Helotiales, Leotiales, Erisyphales, Pezizales (e.g., Helvella sp. and Terfezia boudieri), and Lecythophora were found on several alpine plants (i.e., K. myosuroides, Polygonum viviparum, and Salix herbacea) (Schadt and Schmidt 2001; Ali and Hossein 2008; Mühlmann et al. 2008; Mühlmann and Peintner 2008a, b). Those ascomycetes may be plant endophytes (dark septate fungi and/or arbuscular mycorrhizae), indicating that fungi of different functions, i.e., multiple infections, may coexist within mycorrhizal root tips (Menkis et al. 2005; Wagg et al. 2008) or, alternatively, are opportunistic infections.

General mycobionts of alpine plants

No specificity by EMF communities for plant species and sampling season was detected in our sample size. Similar OTU richness of Inocybe was found on the two plant species during the three sampling seasons, and Tomentella/ Thelephora and Inocybe were OTU-rich genera for each species and for each season/each plant. Mühlmann et al. (2008) and Mühlmann and Peintner (2008a, b) also found that Tomentella/Thelephora and Inocybe were species-rich mycobiont genera of alpine plants in Europe. Thus, the two may be the general and dominant mycobiont genera of plant species during all seasons plus being generalists with more ecological plasticity to environmental changes than other microbionts in alpine areas.

Dauciform roots colonized by EMF

Our observations revealed that dauciform roots were produced by two species of Kobresia, and it is noteworthy that they were colonized by EMF. Dauciform roots, commonly produced in nutrient-impoverished soils, are able to enhance nutrient acquisition of plants. They have been observed on several other plants in the Cyperaceae (e. g., Caustis blakei and Schoenus unispiculatus) in response to phosphorus deficiency (Playsted et al. 2006; Shane et al. 2004). Dauciform roots colonized by EMF, however, have not been reported previously. For both plants and fungi, production of dauciform roots with EMF might be the result of ecophysiological adaptation to alpine adversity, where environmental conditions cause difficulties in nutrient acquisition.

Acknowledgments We thank Dr. Karl-Heinz Rexer and Dr. Kathrin Donges, University of Marburg, for their suggestions in storing of materials and DNA extraction. Dr. David E. Boufford, Harvard University Herbaria, and Dr. Eric Harris, Osher Research Center of Harvard Medical School, are acknowledged for improving the English. This study was supported by the National Science Foundation for Distinguished Young Scholars of China (grant no. 30525002), Joint Funds from the National Natural Science Foundation of China and Yunnan Provincial Government (grant no. U0836604), the National Basic Research Program of China (grant no. 2009cb522300), and the Knowledge Innovation Program of the Chinese Academy of Sciences (grant no. kscx2-YW-G-025). Field work was partially supported by the National Science Foundation of the USA (grant DEB-0321846 to David E. Boufford and Richard H. Ree).

Open Access This article is distributed under the terms of the Creative Commons Attribution Noncommercial License which permits any noncommercial use, distribution, and reproduction in any medium, provided the original author(s) and source are credited.

\section{References}

Agerer R (2006) Fungal relationships and structural identity of their ectomycorrhizae. Mycol Progress 5:67-107

Ali A, Hossein S (2008) Mycorrhiza between Kobresia bellardii (All.) Degel and Terfezia boudieri Chatin. Turk J Bot 32:17-23

Cairney JWG, Chambers SM (eds) (1999) Ectomycorrhizal fungikey genera in profile. Springer, Berlin

Fontana A (1963) Micorrhize ectotrofiche in una Ciperaceae: Kobresia bellardii Degl. Giorn Bot Ital 70:639-641

Gardes M, Bruns TD (1993) ITS primers with enhanced specificity for basidiomycetes - application to the identification of mycorrhizae and rusts. Mol Ecol 2:113-118

Gardes M, Dahlberg A (1996) Mycorrhizal diversity in arctic and alpine tundra: an open question. New Phytol 133:147-157 
Haselwandter K, Read DJ (1980) Fungal associations of roots of dominant and sub-dominant plants in high-alpine vegetation systems with special reference to mycorrhiza. Oecologia 45: $57-62$

Hibbett DS, Vilgalys R (1993) Phylogenetic relationships of Lentinus (Basidiomycotina) inferred from molecular and morphological characters. Syst Bot 18:409-433

Kohn LM, Stasovski E (1990) The mycorrhizal status of plants at Alexandra Fiord, Ellesmere Island, Canada, a high arctic site. Mycologia 82:23-35

Li AR, Guan KY (2007) Mycorrhizal and dark septate endophytic fungi of Pedicularis species from northwest of Yunnan Province, China. Mycorrhiza 17:103-109

Lipson DA, Schadt CW, Schmidt SK, Monson RK (1999) Ectomycorrhizal transfer of amino acid-nitrogen to the alpine sedge Kobresia myosuroides. New Phytol 142:163-167

Margalef DR (1958) Information theory in ecology. Gen Syst 3:36-71

Massicotte HB, Melville LH, Peterson RL (1998) Anatomical aspects of field ectomycorrhizas on Polygonum viviparum (Polygonaceae) and Kobresia bellardii (Cyperaceae). Mycorrhiza 7:287-292

Menkis A, Vasiliauskas R, Taylor AFS, Stenlid J, Finlay R (2005) Fungal communities in mycorrhizal roots of conifer seedlings in forest nurseries under different cultivation systems, assessed by morphotyping, direct sequencing and mycelial isolation. Mycorrhiza 16:33-41

Moreau PA, Mleczko P, Ronikier M, Ronikier A (2006) Rediscovery of Alnicola cholea (Cortinariaceae): taxonomic revision and description of its mycorrhiza with Polygonum viviparum (Polygonaceae). Mycologia 98:468-478

Mühlmann O, Peintner U (2008a) Mycobionts of Salix herbacea on a glacier forefront in the Austrian Alps. Mycorrhiza 18:171-180

Mühlmann O, Peintner U (2008b) Ectomycorrhiza of Kobresia myosuroides at a primary successional glacier forefront. Mycorrhiza 18:355-362

Mühlmann O, Bacher M, Peintner U (2008) Polygonum viviparum mycobionts on an alpine primary successional glacier forefront. Mycorrhiza 18:87-95

Muthukumar T, Udaiyan K, Shanmughavel P (2004) Mycorrhiza in sedges - an overview. Mycorrhiza 14:65-77
Pielou EC (1969) An introduction to mathematical ecology. Wiley, New York

Playsted CWS, Johnston ME, Ramage CM, Edwards DG, Cawthray GR, Lambers H (2006) Functional significance of dauciform roots: exudation of carboxylates and acid phosphatase under phosphorus deficiency in Caustis blakei (Cyperaceae). New Phytol 170:491-500

Read DJ, Haselwandter K (1981) Observations on the mycorrhizal status of some alpine plant communities. New Phytol 88:341-352

Rinaldi AC, Comandini O, Kuyper TW (2008) Ectomycorrhizal fungal diversity: separating the wheat from the chaff. Fung Diver 33:1-45

Schadt CW, Schmidt SK (2001) Characterization of the ectomycorrhizal fungi associated with Kobresia myosuroides. In: Abstracts of Joint Meeting of the American Phytopathological Society. The Mycological Society of America, and the Society of Nematologists, August 25-29, 2001, Salt Lake City, Utah, USA. Phytopathology 91: S122

Shane MW, Dixon KW, Lambers H (2004) The occurrence of dauciform roots amongst Western Australian reeds, rushes and sedges, and the impact of phosphorus supply on dauciform-root development in Schoenus unispiculatus (Cyperaceae). New Phytol 165:887-898

Shane MW, Cawthray GR, Cramer MD, Kuo J, Lambers H (2006) Specialized 'dauciform' roots of Cyperaceae are structurally distinct, but functionally analogous with 'cluster roots'. Plant Cell Environ 29:1989-1999

Shannon CE, Wiener W (1949) The mathematical theory of communication. University of Illinois Press, Urbana

Smith SE, Read DJ (1997) Mycorrhizal symbioses, 2nd edn. Academic, London

Wagg C, Pautler M, Maaicotte HB, Peteron RL (2008) The cooccurrence of ectomycorrhizal, arbuscular mycorrhizal, and dark septate fungi in seedlings of four members of the Pinaceae. Mycorrhiza 18:103-110

Wang B, Qiu YL (2006) Phylogenetic distribution and evolution of mycorrhizas in land plants. Mycorrhiza 16:299-363

Wu CY, Zhu YC (1987) The vegetation of Yunnan. Science, Beijing Zhou XM (2001) The Kobresia meadow of China. Science, Beijing 